\title{
Erratum to: The State of the Art of Hybrid RANS/LES Modeling for the Simulation of Turbulent Flows
}

\author{
Bruno Chaouat ${ }^{1}$
}

Published online: 1 September 2017

(c) Springer Science+Business Media B.V. 2017

\section{Erratum to: Flow Turbulence Combust (2017) 99:279-327 DOI 10.1007/s10494-017-9828-8}

The article "The State of the Art of Hybrid RANS/LES Modeling for the Simulation of Turbulent Flows", written by Bruno Chaouat, was originally published Online First without open access. After publication in volume 99, issue 2, page 279-327 the author decided to opt for Open Choice and to make the article an open access publication. Therefore, the copyright of the article has been changed to (C) The Author(s) 2017 and the article is forthwith distributed under the terms of the Creative Commons Attribution 4.0 International License (http://creativecommons.org/licenses/by/4.0/), which permits use, duplication, adaptation, distribution and reproduction in any medium or format, as long as you give appropriate credit to the original author(s) and the source, provide a link to the Creative Commons license, and indicate if changes were made. 